\title{
Korea's Future Policy Recommendation for the Promotion of Eco-Friendly Vehicles in Metropolitan Area
}

\author{
Won Shik Shin ${ }^{1,2}$ \\ 1. Graduate School of Knowledge Based Technology and Energy, Korea Polytechnic University, 237 Sangidaehak-ro, Siheung-si, \\ Gyeonggi-do 15073, Korea \\ 2. President of Korea Association for Natural Gas Vehicles (KANGV), 2nd Floor KOGAS, 340 Gonghang-daero, Gangseo-gu, Seoul \\ 07647, Korea
}

Received: April 18, 2017 / Accepted: April 26, 2017 / Published: June 30, 2017.

\begin{abstract}
This paper introduces and analyzes Korea's NGV (natural gas vehicles) policy for soot-free bus fleet which intends to promote CNG (compressed natural gas) bus in metropolitan area for the reduction of air pollution from road sector. At the early stage, Korean government established various supporting policy systems to encourage public transportation companies to purchase CNG buses as a means to replace diesel buses. It was evaluated as very successful with making net economic benefit of CNG bus promotion policy. During the 2nd stage, Korean government implemented CNG hybrid bus promotion policy to further reduce both air pollution and greenhouse gas. Now, a new social demand for the vehicles is zero-emission vehicles. The author asserts that current FCEV (fuel cell electric vehicle) should be considered as an alternative to zero-emission vehicles in Korea and suggests policy recommendation for the promotion of FCEV by referring the current CNG bus promotion policy in public transportation sector.
\end{abstract}

Key words: Korea's NGV promotion policy, air pollution, government subsidy, environmental benefit, CNG bus, CNG hybrid bus, zero-emission vehicles, FCEV.

\section{Introduction}

In Korea the number of vehicles has increased so rapidly with the high-speed economic growth since 1970. There were only 130 thousand vehicles in 1970 , but the number increased to almost 12 million in 2000 and 21 million at the end of year 2015. This sharp increase of vehicles had much contributed to deepening the problem of air pollution, particularly in the metropolitan area. In 2001 PM (particulate matter) concentration in the air in Seoul was 71 micrograms per cubic meter, which was two times higher than other global cities such as London, Paris, Tokyo and New York as shown in Fig. 1.

An analysis on air pollution source in metropolitan areas (Seoul, Gyunggi Province and Incheon City)

Corresponding author: Won Shik Shin, Ph.D. Candidate, research fields: government policy on eco-friendly vehicles, energy economics and policy. showed that PM emission volume to the air was over 9,500 tons per annum. Among that, approximately 4,000 tons have been emitted from the road transportation sector, the source with the highest contribution rate of $41.2 \%$. And further, it was confirmed that diesel vehicles like trucks and buses which only take up less than $22 \%$ of the total vehicles were the leading sources of PM, accounting for $62 \%$ of the PM emissions from the road transportation sector as shown in Fig. 2 [1].

Since the 1990s, Korean Government MOE (Ministry of Environment) implemented three kinds of policy measures in order to reduce air pollution from road sector. The first one was the strengthening of vehicle emission standard by adopting EURO 1 through 6 in phase. The second one was after-measure of installing "emission reduction device" like DPF (diesel particulate filter) for diesel vehicles. 


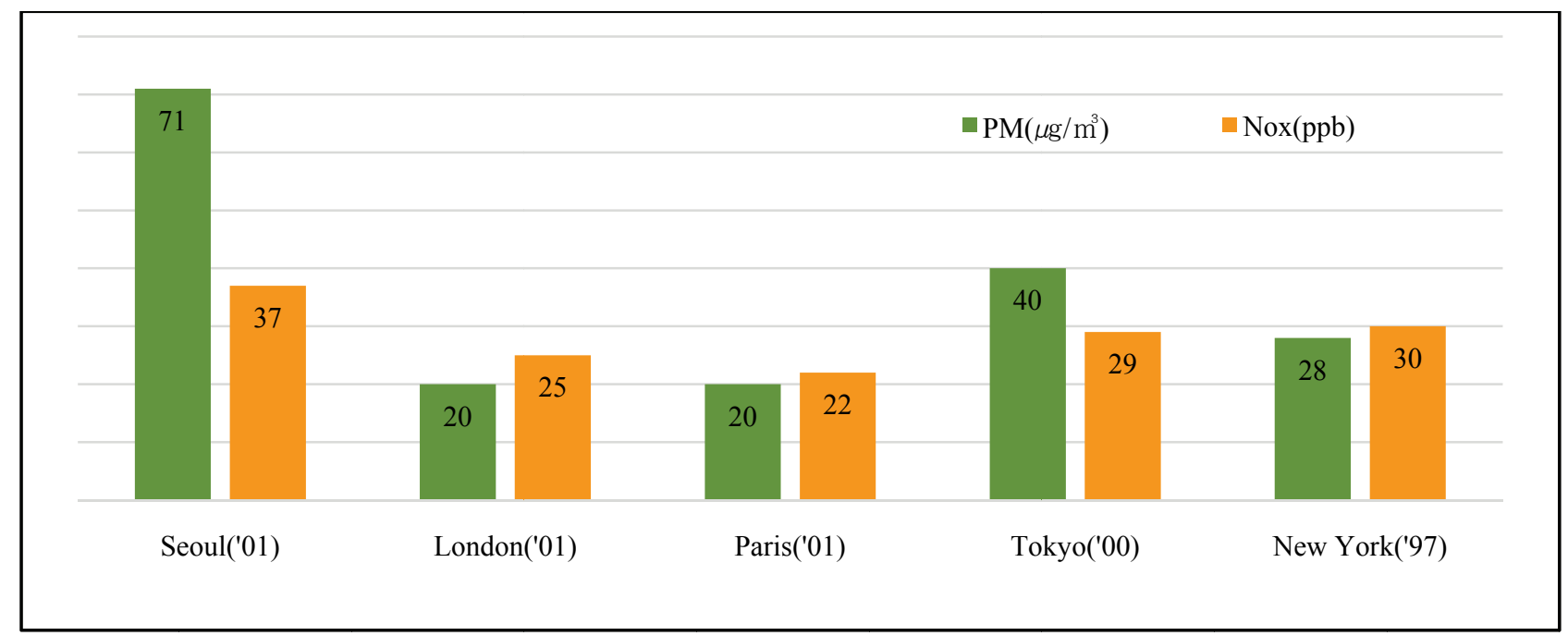

Fig. 1 Air pollution comparison.

Source: Ministry of Environment, Korea.

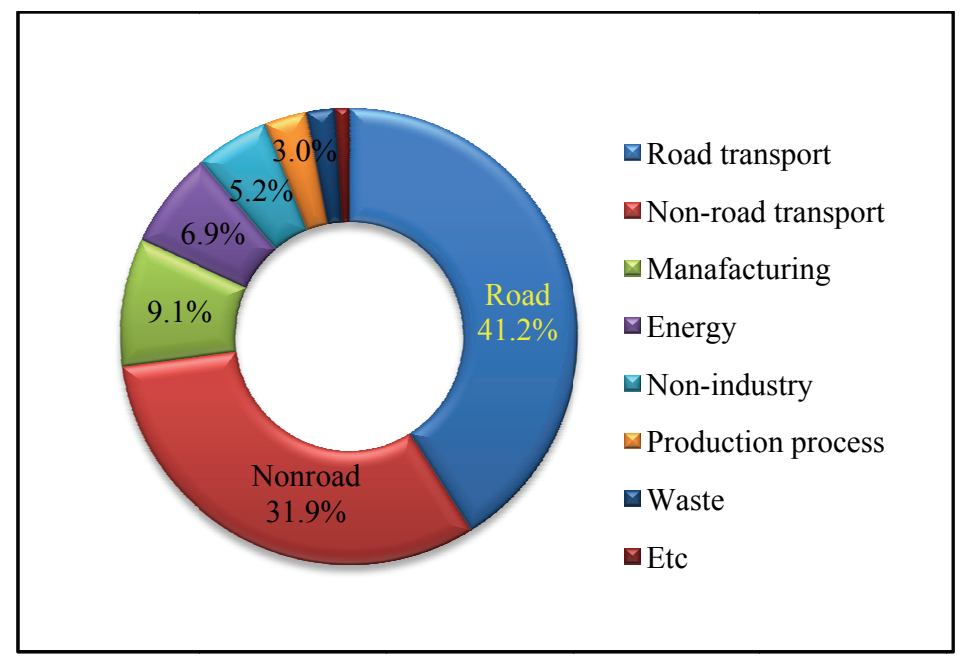

PM10 emission by vehicle type in the transport sector

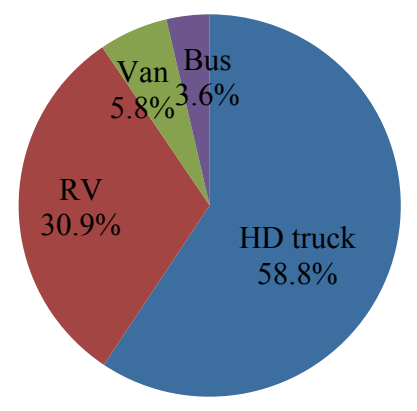

- HD truck

- RV

- Van

- Bus

- PV

- Special

Fig. 2 Sources of air pollution.

Sources of air pollution [PM10] in metropolitan area.

Source: National Institute of Environmental Research, Korea, 2012. 
It became mandatory in 2005 to install DPF in every diesel vehicle. The third one was the promotion of eco-friendly vehicles such as EV (electric vehicles) and NGV (natural gas vehicles). However, to the public transportation sector including big-sized buses, Korea's Ministry of Environment concluded that the most effective measure was to replace diesel bus with CNG (compressed natural gas) bus. Because that measure had some of advantages including its eco-friendly characteristics by reduction of air pollutant material, merits of $\mathrm{CNG}$ fuel price and the availability of CNG refueling stations in metropolitan area. A test result conducted by KEI (Korea Environment Institute) in 2012 showed that the emission gas of CNG buses had the reduction of $100 \%$ of $\mathrm{PM}, 64.7 \%$ of $\mathrm{NO}_{\mathrm{x}}, 96.8 \%$ of $\mathrm{CO}$ comparing to that of diesel bus [2].

Since the late 1990s, Korea's MOE has initiated and created NGV market by replacing diesel buses with CNG buses for the public transportation in metropolitan area. And that policy has achieved a huge success that resulted in the reduction of air pollution and its social benefit was higher than its social cost supported by the government.

However, in the future, most of the transportation will further require the zero-emission and full eco-friendly vehicles and Korean government should guide and support this policy direction for the preparation of the automobile industry. In this regard, future policy recommendation should be based on CNG bus promotion policy. One of the right strategies in CNG bus promotion was to select public transportation bus in metropolitan area as policy target, which had public garage to accommodate the bus fleet and $\mathrm{CNG}$ refueling station at the same location.

In the future, EV and FCEV (fuel cell electric vehicles) will compete with each other as full zero-emission vehicles. However the weight of coal-fired power plant in total Korea's gross generation is accounting for $39.1 \%$ in 2014 , followed by $30.0 \%$ of nuclear power in 2014 [3], which causes a lot of air pollution with $\mathrm{PM}, \mathrm{NO}_{\mathrm{x}}$ and $\mathrm{SO}_{\mathrm{x}}$, and makes the greenhouse gas of $\mathrm{CO}_{2}$. The $\mathrm{CO}_{2}$ volume of power plants, the main portion of which is created by coal fired power plants, is accounting for about $45.3 \%$ of total $\mathrm{CO}_{2}$ volume in energy sector [4]. If we consider the significant contribution of coal-fired power plants to air pollution and greenhouse gas, currently EV in Korea should be reconsidered as an alternative to zero-emission vehicles. Mr. Bjorn Lomborg argues that electric cars run on electricity, which in the US is often produced by another fossil fuel-coal. As green venture capitalist Vinod Khosla likes to point out, "Electric cars are coal-powered cars". Today, the US gets only $14 \%$ of its electric power from renewable [5].

Therefore, FCEV should be solely studied as a final alternative for pure zero-emission vehicles. In order to promote FCEV the Korean government should work for the proper supporting system at the early stage as it did in case of $\mathrm{CNG}$ bus. Here the policy recommendation for $\mathrm{FCEV}$ can be proposed by referring to the success case of $\mathrm{CNG}$ bus promotion in metropolitan area.

\section{Korea's NGV Policy for Soot-Free Bus Fleet}

The Korean government among Ministry of Environment, Ministry of Knowledge Economy, and Ministry of Science \& Technology supported R\&D for CNG bus technology during 1992 and 1998. And pilot operation on the road was followed by CNG bus manufacturers. In the case of passenger cars, automakers are likely to put a limited offering of model types on the market at the early stage with restricting consumer choices because of lack of market demand. Also the passenger car owners may have difficulties finding out the refueling stations nearby on the street. Therefore, the early vehicles should be deployed in fleets like public bus. Because CNG bus fleet can share a refueling station, which allows to save the capital investment and to make an 
economy of scale in the business operation of refueling stations.

In the meantime, regulatory foundation was set up during 1999 and 2000 with the amendment of "Clean Air Conservation Act" and "Special Act on Metropolitan Air Quality Improvement", which established a legal basis for $\mathrm{NGV}$ promotion as low-emission vehicles. In Korea, the supply of CNG buses on commercial basis began in 2000 and became more scaled-up during 2002 World Cup Season for providing foreign guests cleaner air condition. After 2005, NGV became also available in garbage trucks and intra city bus models.

At the early stage, Korean Ministry of Environment established various supporting policy systems to encourage public transportation company replacing diesel buses with CNG buses as shown in Fig. 3: (1) government subsidy for $\mathrm{CNG}$ bus purchasing amounting to US\$11 $\mathrm{K}$ in case of large-sized bus which was shared between state and local government;
(2) fuel cost assistance to maintain over US $\$ 0.063 / \mathrm{m}^{3}$ price difference from diesel; (3) tax exemption of VAT and acquisition tax for the vehicle and corporate tax for the CNG station operator; (4) low interest rate loan for $\mathrm{CNG}$ refueling station construction.

On the other hand, Ministry of Knowledge Economy amended "High-Pressure Gas Safety Control Act" to establish technical standards for the construction of $\mathrm{CNG}$ refueling stations and the manufacturing of fuel containers [6].

According to the strong government support, the number of CNG buses rose from 1,376 units in 2003 to 31,115 units in 2015 . At the end of $2015,81 \%$ of inner-city buses are running on $\mathrm{CNG}$ with $98 \%$ running in 6 major cities. And the total $\mathrm{CNG}$ refueling stations were 197 nationwide [7].

As the result, PM concentration rate in metropolitan area had been much reduced from 63 micrograms per cubic meter in 2005 to 51 micrograms per cubic meter in 2015 [8].

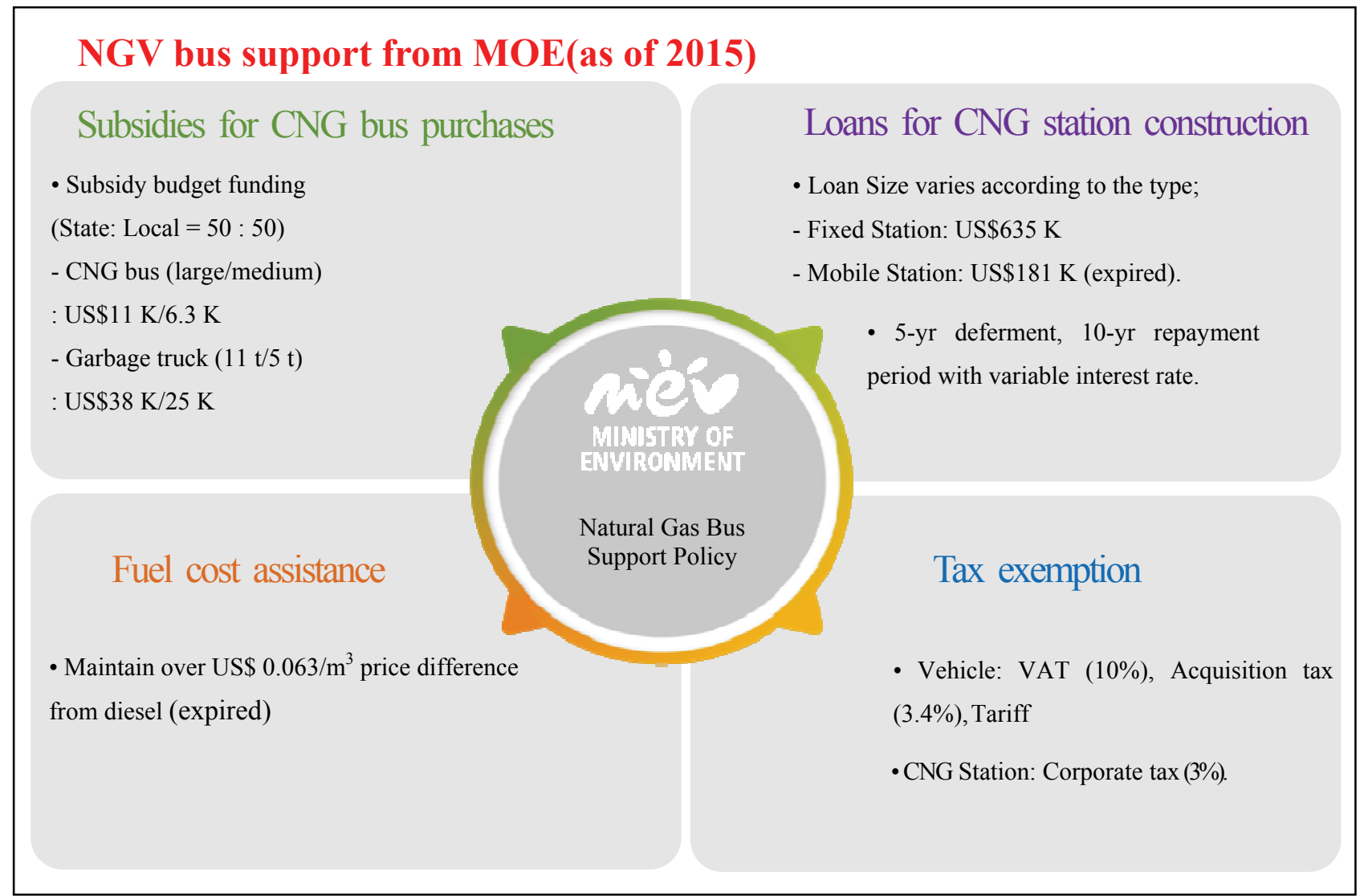

Fig. 3 Government support. 


\subsection{Evaluation of the Policy Achievement}

After years of subsidy and promotion, the achievement of $\mathrm{CNG}$ bus promotion policy was evaluated by comparing government supporting cost and social benefit. CNG bus promotion helped reduce vehicle pollutant emission and improve atmospheric environment of metropolitan areas. However, the government paid the cost for its promotion with $\mathrm{CNG}$ bus purchasing subsidy and low interest rate loan for the construction of $\mathrm{CNG}$ refueling stations.

According to the study by Korea Environment Policy and Evaluation Institute in 2009, net economic benefit of $\mathrm{CNG}$ bus promotion policy was reaching about U\$1 billion which was calculated by comparing the government supporting estimated cost and social environmental benefit of $\mathrm{CNG}$ buses purchased between 2000 and 2008 as shown in Table 1 [9].

The methodology for the calculation of environmental benefit was as follows:

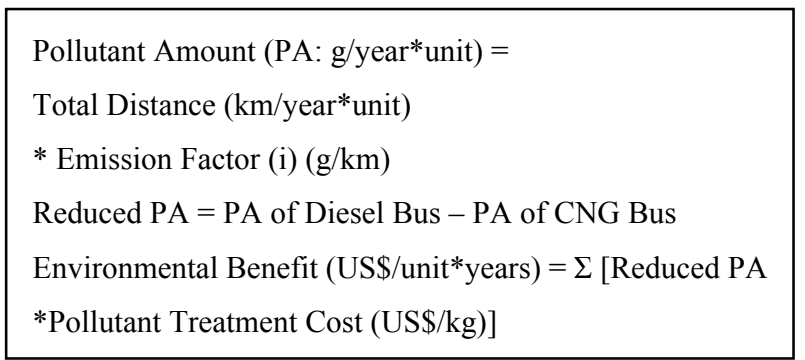

Remark: Social marginal cost for the pollutant treatment was applying EC data in case of $\mathrm{PM}, \mathrm{NO}_{\mathrm{x}}, \mathrm{HC}$ and applying UNEP and KAIST data in case of CO.
As the result, the average net economic benefit per CNG bus was about US\$53 thousands during 10 years of duration period (US\$1,011 million of net economic benefit/19,078 units of the accumulated CNG buses). That means a very appropriate policy design. Because the policy provided a good reasoning of government subsidy which could encourage public bus companies substituting diesel buses with CNG buses. US\$53 thousands is about half of one unit of $\mathrm{CNG}$ bus purchasing price (US\$106 thousands).

Korea's CNG bus promotion policy implementation is centered around three different ministries with full cooperation from the local governments. Ministry of Environment establishes comprehensive promotion plan and provides supporting funds with government budget. Ministry of Land, Infrastructure and Transportation is administering certification of vehicles and their parts and also in charge of safety management. Ministry of Trade, Industry and Energy (in the previous Ministry of Knowledge Economy) deals with safety regulations of CNG stations and the management. And also it is responsible for R\&D of vehicles and their parts. At the level of local government Seoul City is the most active in supporting CNG buses on the road with its own budget.

In 2014 PM concentration rate in the air in Seoul was down to 44 micrograms per cubic meter from 71 micrograms per cubic meter in 2001.

Table 1 Analysis on economic benefit of CNG bus promotion policy.

(Unit: US\$ million)

\begin{tabular}{|c|c|c|c|c|c|c|c|c|c|c|c|}
\hline \multicolumn{2}{|c|}{ Classification } & 2000 & 2001 & 2002 & 2003 & 2004 & 2005 & 2006 & 2007 & 2008 & Total \\
\hline \multicolumn{2}{|c|}{ Environmental benefit } & 5.4 & 77.3 & 220.0 & 177.5 & 238.2 & 292.4 & 292.6 & 285.6 & 92.1 & $1,681.1$ \\
\hline \multirow{5}{*}{$\begin{array}{l}\text { Cost } \\
\text { by gov't } \\
\text { support }\end{array}$} & CNG bus purchasing subsidy & 1.2 & 13.7 & 40.0 & 31.3 & 36.2 & 50.9 & 66.5 & 62.2 & 79.6 & 381.6 \\
\hline & Fuel cost assistance & 0 & 0 & 1.7 & 3.7 & 5.1 & 6.9 & 8.6 & 9.7 & 10.0 & 45.7 \\
\hline & Tax exemption & 0.7 & 7.6 & 22.1 & 17.3 & 19.9 & 28.1 & 39.9 & 38.2 & 48.0 & 221.7 \\
\hline & Support for CNG station & 0.5 & 1.0 & 5.6 & 2.5 & 2.6 & 2.0 & 1.9 & 2.8 & 1.9 & 20.9 \\
\hline & Sub total & 2.3 & 22.4 & 69.5 & 54.9 & 63.8 & 87.8 & 116.8 & 112.8 & 139.5 & 669.9 \\
\hline \multicolumn{2}{|c|}{ Net economic benefit } & 3.1 & 55.0 & 150.5 & 122.6 & 174.4 & 204.6 & 175.7 & 172.7 & -47.4 & $1,011.2$ \\
\hline
\end{tabular}

Remark:

(1) Exchange rate between U\$ and Korean Won is 1,125, which is the average of 2000-2008.

(2) Applying 10 years of durable period for CNG bus in calculation of benefit and cost of CNG bus promotion policy. 


\subsection{Promotion of CNG Hybrid Bus}

With experiencing a successful promotion of $\mathrm{CNG}$ bus, Korean government has implemented CNG hybrid bus promotion policy to further reduce air pollution as well as greenhouse gas. According to the research conducted by KANGV in 2012, CNG hybrid bus achieved about $30 \%$ of fuel efficiency which resulted in reduction of air pollutants like $\mathrm{CO}, \mathrm{HC}$, $\mathrm{NO}_{\mathrm{x}}$ as well as greenhouse gas like $\mathrm{CO}_{2}$ and $\mathrm{CH}_{4}$ as shown in Table 2 [10].

Because the price difference between the unit price of CNG bus and CNG hybrid bus is about US\$54,550, total social benefit of CNG Hybrid bus compared to CNG bus is US\$34,330 higher than the price difference between the two (US\$54,550). With this in mind, since 2012 Korean government has began to promote CNG hybrid bus in big cities by supporting purchasing subsidy amounting to US\$54,500 per unit and now total $211 \mathrm{CNG}$ hybrid buses are running on the road as of December 2016, which is about $0.8 \%$ of total $\mathrm{CNG}$ buses registered in 2016. The Korean government expects that this policy will mark the 2 nd successful story followed by CNG promotion policy.

\section{Future Policy Recommendation for the Promotion of Zero-Emission Vehicles}

Now, a new social demand and government regulation for the vehicles is requiring zero-emission of air pollutants and greenhouse gas. Considering the big contribution of coal-fired power plants to air pollution which is including particulate matter and greenhouse gas in Korea, currently EV should be excluded as an alternative for zero-emission vehicle. But FCEV should be studied as an alternative for that. US DOE (Department of Energy) described positive attributes of hydrogen as an energy carrier with producing near-zero emissions of greenhouse gases and criteria pollutants from renewable (hydro, wind, solar, geothermal, biomass) and nuclear sources and from fossil fuel-based systems by carbon sequestration. However, in the near term distributed natural gas should be a good source of hydrogen made by its reforming method [11].

One of the effective policies for the promotion of FCEV is to apply the CNG bus promotion policy in public transportation sector as fleet at the early stage of vehicle development. Because in the early stage it is not so effective to promote passenger cars of FCEV due to the low economy by high operation cost of hydrogen refueling stations. And small number of refueling stations may give inconvenience to personal FCEV owner. In this regard Hydrogen Posture Plan of US DOE also mentions that most states are now developing strategies for reaching national air quality goals and hydrogen-based commercial bus fleet is one of the approaches [11].

There are a couple of issues to be considered to establish the promotion policy by the Korean government. First, the price of FCEV bus is too high to be purchased by the bus company without much support from the government. Currently as of the end of 2016 the price of diesel bus is US\$90.0 thousands and the price of FCEV bus is about US\$666.7 thousands. If the sum of environmental cost and tax

Table 2 Total social benefit of CNG hybrid bus via CNG bus.

\begin{tabular}{lllllll}
\hline Classification & $\mathrm{CO}$ & $\mathrm{HC}$ & $\mathrm{NOx}$ & $\mathrm{CO}_{2}$ & $\mathrm{CH}_{4}$ & Total \\
\hline Reduction rate of CNG hybrid & $27.9 \%$ & $15.6 \%$ & $46.9 \%$ & $25.6 \%$ & $41.7 \%$ & \\
$\begin{array}{l}\text { Improvement of environmental } \\
\text { cost for 9 years }\end{array}$ & $\mathrm{US} \$ 64.5$ & $\mathrm{US} \$ 675.5$ & $\mathrm{US} \$ 15,640.0$ & $\mathrm{US} \$ 4,784.5$ & $\mathrm{US} \$ 940.0$ & $\mathrm{US} \$ 22,104.5$ \\
$\begin{array}{l}\text { Saving of fuel cost for 9 years } \\
\text { Total social benefit }\end{array}$ & & & & & US $\$ 66,776.3$ \\
\hline
\end{tabular}

Source: Analysis on the effectiveness of pilot operation of CNG hybrid bus, MOE. 
Table 3 Total social cost for the operation of diesel bus.

(Unit: US\$ thousand)

\begin{tabular}{lll}
\hline & Sub cost & Total \\
\hline Environmental cost & $\mathrm{PM} 22.6, \mathrm{CO} 7.0, \mathrm{HC} 1.1, \mathrm{NO}_{\mathrm{x}}$ 92.4, & 140.9 \\
& $\mathrm{CO}_{2} 17.8$ & 129.0 \\
Gov't support & Acquisition tax exemption 2.1, & 129.0 \\
\hline
\end{tabular}

Source: Analysis on the effectiveness of pilot operation of CNG hybrid bus, MOE.

Table 4 A policy design for FCEV promotion.

\begin{tabular}{|c|c|c|}
\hline & Current policy in Korea & Future policy recommendation \\
\hline Vehicles & $\begin{array}{l}\text { Purchasing subsidy: US } \$ 167 \mathrm{~K} \\
\text { (shared by state and local) }\end{array}$ & Current purchasing subsidy + tax exemption \\
\hline Refueling station & $\begin{array}{l}\text { Construction subsidy: US\$1,250 K } \\
\text { for the capacity of } 500 \mathrm{~kg} / \text { day }\end{array}$ & Current construction subsidy + operating loss \\
\hline $\begin{array}{l}\text { Total subsidy } \\
\text { per vehicle unit }\end{array}$ & Total subsidy for 9 years: US\$204 K* & $\begin{array}{l}\text { Total subsidy for } 9 \text { years } \leq \text { US } \$ 270 \mathrm{~K} \\
+ \text { fuel cost saving of Hydrogen } \\
+ \text { social external effect }\end{array}$ \\
\hline
\end{tabular}

$* 167 \mathrm{~K}+(1,250 \mathrm{~K} \div 15 * 9 \div 20$ units $)$.

exemption amount for diesel bus is US\$270 thousands as shown in Table 3 [10], a reasonable guideline of the promotion policy would be that the total government support for FCEV buses should not be higher than US\$270 thousands. In that case, the actual purchasing price of FCEV bus companies should be US\$396.7 thousands per unit which is four times higher than the price of diesel bus.

According to one of Korean automakers, it has the plan to produce FCEV bus within US\$420 thousands per unit by 2019 on mass production basis. In order to actualize this scenario FCEV bus manufacturer should make endeavors to reduce the production cost through R\&D and mass production.

Without reflecting the production cost reduction, currently a policy design for the promotion of FCEV bus fleets can be recommended as follows.

As shown in Table 4, currently the total Korean government supporting amount which is including purchasing subsidy of FCEV bus and construction subsidy of hydrogen refueling station is US\$204 thousands for 9 years of operation, if construction cost of refueling station is depreciated in 15 years. If a reasonable guideline of the total subsidy by the government is up to US\$270 thousands which are a net social benefit of FCEV bus operation, the rest of US\$66 thousands can be allocated for future policy recommendation like tax exemption for vehicle purchase and support for the operation loss of the refueling station. However, there are two more considering factors in order to decide the government supporting policy: (1) fuel cost saving of hydrogen and (2) external social benefit of FCEV bus by contributing early realization of hydrogen economy as a new energy source for the nation. The social external effect could be measured in each government taking into consideration of its own policy target and government will. This point should differentiate FCEV promotion policy from $\mathrm{CNG}$ bus promotion policy.

Second, construction cost and safety issue of hydrogen refueling station should be studied and taken care of by R\&D endeavors jointly by the government and private sector. In some cases, anxiety of the people living near hydrogen refueling station regarding the risk of explosion of hydrogen storage tank should be taken care of by sufficient explanation and education on the safety of hydrogen refueling station. One way is to operate hydrogen refueling station at $\mathrm{CNG}$ bus parking lot which is usually located in remote area from the residence.

Third, in case of reforming method from CNG the concept of Mother \& Daughter station should be studied for the promotion of FCEV passenger vehicles. 
After some years of FCEV bus operation Mother station located in public bus transportation poking lot should produce hydrogen and transport some to Daughter station located on city road for FCEV passenger vehicles.

\section{Conclusions}

This paper assessed the effect of Korea's CNG bus promotion policy by comparing social cost and social benefit of CNG bus operation in replacing diesel bus. And it showed the contribution of this policy to reduce the air pollution in metropolitan area of Korea.

Nowadays, air quality and greenhouse gas issues are still acknowledged as serious matters which should be taken care of by the new "Moon Jae-In government" in Korea. The new government should also establish the new policy direction for eco-friendly vehicles in metropolitan area because the contribution rate of transportation energy consumption is accounting for about $30 \%$ of total air pollution. One of the important promotion policies for eco-friendly vehicles is government's purchasing subsidy on vehicles and supports on refueling stations.

In this regard, the policy recommendation for the promotion of FCEV in this paper should be a good reference, because the ordinary people should also understand and agree on the grounds for government's subsidy which is made by tax.

Future work will be to calculate the amount of external social benefit of FCEV which is a different and additional value for FCEV compared with CNG vehicles.

\section{References}

[1] KANGV. 2016. Korea's Policy on NGV for Soot Free Bus. CCAC Workshop.

[2] Korea Environment Institute. 2012. Feasibility Study on CNG Bus Promotion Policy in Terms of Analysis of Environmental and Economic Characteristics. MOE, Korea, 74.

[3] Ministry of Trade, Industry \& Energy. 2015. The 7th National Plan for Electric Demand and Supply (2015-2029). Korea, Press Release.

[4] Korea Energy Economics Institute. 2016. www.keei.re.kr, Korea.

[5] Bjorn Lomborg. "Are Electric Cars Really Green?" PragerU.com.

[6] MOE. 2009. Master Plan of NGV Promotion and Related Laws and Regulations. Korea, 14-6.

[7] Ministry of Land, Infrastructure \& Transportation. 2016. www.molit.go. kr, Korea.

[8] Jun, E. C. 2017. "Environment \& Energy Policy Recommendation for the Counter-Measure of Climate Change and the Air Contamination by PM.” Presented at the Seminar for Tax System in Energy Sector, Korean National Assembly.

[9] Korea Environment Institute. 2009. Evaluation on the Achievement of $\mathrm{CNG}$ Vehicles Promotion Policy and Future's Reasonable Policy Recommendation for the Stable Promotion. MOE, 17-52.

[10] KANGV. 2012. Analysis on the Effectiveness of Pilot Operation of CNG Hybrid Bus. MOE.

[11] US Department of Energy \& US Department of Transportation. 2006. Hydrogen Posture Plan. 